\begin{tabular}{|c|c|c|c|c|c|c|}
\hline \multirow{4}{*}{ Impact Factor: } & ISRA (India) & $=3.117$ & SIS (USA) & $=0.912$ & ICV (Poland) & $=6.630$ \\
\hline & ISI (Dubai, UAE & $=0.829$ & РИНЦ (Russia) & $=0.156$ & PIF (India) & $=1.940$ \\
\hline & GIF (Australia) & $=0.564$ & ESJI (KZ) & $=5.015$ & IBI (India) & $=4.260$ \\
\hline & JIF & $=1500$ & & & & \\
\hline
\end{tabular}

SOI: $\underline{1.1 / \mathrm{TAS}}$ DOI: $\underline{10.15863 / \mathrm{TAS}}$

International Scientific Journal Theoretical \& Applied Science

p-ISSN: 2308-4944 (print) e-ISSN: 2409-0085 (online)

Year: $2018 \quad$ Issue: 12 Volume: 68

Published: 26.12.2018 http://T-Science.org

SECTION 9. Chemistry and chemical technology.
QR - Issue

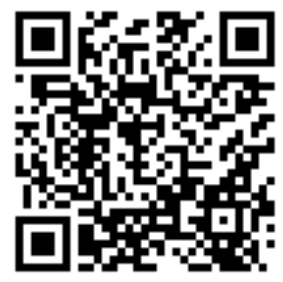

M.T. Sharifova

Institute of Ecology and Natural Resources Ganja Branch of Azerbaijan National Academy of Sciences, Ganja, Azerbaijan sharifova-54@mail.ru

Ch.G. Ismailov

Institute of Ecology and Natural Resources Ganja Branch of Azerbaijan National Academy of Sciences, Ganja, Azerbaijan

A.T. Mammadova

Ganja State University, Ganja, Azerbaijan

E.M. Hajiyeva

Institute of Ecology and Natural Resources Ganja Branch of Azerbaijan National Academy of Sciences, Ganja, Azerbaijan

M.I. Mammadova Institute of Ecology and Natural Resources Ganja Branch of Azerbaijan National Academy of Sciences, Ganja, Azerbaijan

A.M. Hasanova

Ganja State University, Ganja, Azerbaijan

\title{
ABOUT STUDY OF OBTAIN THE DECORATIVE SAND ASPHALT FROM STRIPPING OF ALUNITE FROM ZAYLIK FIELD
}

Abstract: In connection with intensive development of various industrial cities, formed a huge amount of solid waste industry that are taking up a huge suitable land, pollute the environment. Academic and technical progress is associated with the maximum savings of material and energy resources, the creation of non-waste technology, the intensification of technological processes and improved quality products.

One of the effective methods of solid waste disposal industry is their use in the design of various types of asphalt. It should be noted that to date, no research has been conducted on possible use of mineral wastes in the production of asphalt concrete.

Key words: decorative concrete, industrial waste, filler, asphalt.

Language: English

Citation: Sharifova, M. T., Ismailov, C. G., Mammadova, A. T., Hajiyeva, E. M., Mammadova, M. I., \& Hasanova, A. M. (2018). About study of obtain the decorative sand asphalt from stripping of alunite from zaylik field. ISJ Theoretical \& Applied Science, 12 (68), 248-251.

Soi: http://s-o-i.org/1.1/TAS-12-68-36 Doi: croskef https://dx.doi.org/10.15863/TAS.2018.12.68.36

\section{Introduction}

The certification of mountain deposits, carried out by us proved that, the top layer and poor alunite rocks of alunite ore (where the content of useful components is less than 40\%) are 20 million tons [2].
Collecting waste in such huge quantities leads to loss of production and, ultimately, to a sharp increase in the cost of the product produced. In addition, these wastes, when seizing useful land, can cause irreversible damage to the environment. The only 


\begin{tabular}{|c|c|c|c|c|c|c|}
\hline \multirow{4}{*}{ Impact Factor: } & ISRA (India) & $=3.117$ & SIS (USA) & $=0.912$ & ICV (Poland) & $=6.630$ \\
\hline & ISI (Dubai, UAI & $=0.829$ & РИНЦ (Russia) & $=0.156$ & PIF (India) & $=1.940$ \\
\hline & GIF (Australia) & $=0.564$ & ESJI (KZ) & $=5.015$ & IBI (India) & $=4.260$ \\
\hline & JIF & $=1.500$ & SJIF (Morocco) & $=5.667$ & & \\
\hline
\end{tabular}

effective way out of the situation is the processing of large quantities of industrial waste. For this reason, the development of innovative technologies for the disposal of waste mining industry is a requirement of modernity.

Implementation of the national programs on regional development is possible only through the processing of local raw materials and waste using innovative technologies. In this regard, the disposal of industrial waste, along with the creation of wastefree and low-waste industrial sites, is one of the urgent problems. The purpose of the work is to obtain aluminum from alunite mining waste from the Dashkasan field.

\section{Materials and Methods}

In promoting of socio-economic development of the Republic of Azerbaijan, including the improvement of the living conditions of the population of regions, the role of roads meeting modern requirements, is very high. With this end in recent years in the country, at the expense of the state budget and international financial-credit organizations, carried out extensive work on improvement of existing and construction of new roads. To implement these goals, the Republic spent a huge raw material resources.

However, it is known that in connection with intensive development of various industrial cities, formed a huge amount of solid wastes, which, occupying a vast suitable land, pollute the environment. In these circumstances, in recent years, the high demands and to the protection of the environment. Therefore, together with the creation of non-waste or low-waste industrial sites, conducting research on the use of industrial waste. One of the effective methods for the disposal of solid industrial wastes is through its use in the design of various types of asphalt.

Due to the fact, that the preparation of the asphalt concrete high tonnage production, it can create preconditions for recycling of industrial waste. From this point of view, the study of possibility of utilization of industrial wastes in the Western region of the Republic (overburden alunite ore deposits Saglik) in the production of asphalt concrete, along with actuality, are the demand of time. From the analysis of literature it is known that in the preparation of asphalt concrete the main binder is bitumen. The second major component is the filler. From fillers, preference is given to the mineral. Due to the fact, that currently in the Republic of bitumen produced in an industrial scale, research was conducted on the basis of bitumen grade VND-60/90. It should be noted that mining and non-ferrous metallurgy industry are mainly concentrated in the Western region of the country, where there is accumulation of mineral waste.

From studies we have conducted on certification of waste in the Western region, it became known that in this region, along with waste in the production of iron ore and alunite in the blade is going and their overburden (N.I.Taghiyev, Ch.G.Ismailov). Using of industrial wastes in the Western region, as the fillers, were obtained various kinds of construction materials $[1,2,3]$.

It should be noted that to date, no research has been conducted on possible use of mineral wastes in the manufacture of asphalt concrete. With that in mind, we have carried out the research work in this direction. Structural characteristics of concrete as an artificial construction conglomerate, consists of a stone mixture (crushed stone or gravel and sand) coupled in monolith asphalt binder, and a binary system in which the liquid phase, the bitumen-mixed with a fine mineral powder [4].

The formation of the optimal structure of asphalt concrete depends not only on properties of components and production technology, but also on the design of optimal compositions. A method of designing the optimal composition of asphalt concrete is to select the quantitative ratios between the components, which provide the optimal structure and defined technical properties, which take extreme values. At present, there are several methods of designing the composition of asphalt concrete: method of P.V. Sakharov, N.N. Ivanov, Union of DORNIE etc., highest value of which is a method developed Union of DORNIE [5].

Principle of this method is based on the position dependence of strength and other physio-mechanical properties of asphalt concrete density mineral mixture at optimum bitumen content.

The sequence of calculation of composition of asphalt concrete the following:

1. The selection and quality control of the raw materials (bitumen, mineral powder, sand, crushed stone or gravel).

2. Assessment and calculation of the grain composition of the mineral mixture.

3. Testing of samples of asphalt concrete.

The choice of raw material depends on the type and purpose of asphalt concrete and is fully consistent with the relevant requirements of GOST.

Use grain composition of mineral part of asphalt concrete mixtures according to GOST 9128-84 select the ratio between the mineral content of the projected composition of asphalt concrete, the amount of each fraction selected so that the total ratio of all fractions of mineral materials was 100 percent. In addition, the resulting mixture after combining and mixing the batched mineral components must have the highest density [6].

The optimum amount of bitumen are determined by experiment, which of the chosen mineral mixture and bitumen is made several mixes with different content of bitumen. Using standard test specimens to determine the volumetric water saturation and tensile strength under compression. 


\begin{tabular}{|c|c|c|c|c|c|c|}
\hline \multirow{4}{*}{ Impact Factor: } & ISRA (India) & $=3.117$ & SIS (USA) & $=0.912$ & ICV (Poland) & $=6.630$ \\
\hline & ISI (Dubai, UAF & $=0.829$ & РИНЦ (Russia) & $=0.156$ & PIF (India) & $=1.940$ \\
\hline & GIF (Australia) & $=0.564$ & ESJI (KZ) & $=5.015$ & IBI (India) & $=4.260$ \\
\hline & JIF & $=1.500$ & SJIF (Morocco) & $=5.667$ & & \\
\hline
\end{tabular}

The optimum amount of bitumen meets the asphalt mix, the samples which showed the best test results in relation to the requirements of GOST.

In the final stages of design made the control samples of asphalt mix chosen composition test according to the technical requirements of GOST 12801-84 [7]. If necessary, adjust the composition of the asphalt.

Us at the above rules for the preparation of highly porous asphalt concrete taken $91 \%$ wax-red overburden of alunite and 9 percent of bitumen grade VND-60/90.

Physio-mechanical properties of the prepared asphalt mix was determined on cylindrical samples, obtained by compacting the mixture in a steel cylinder. Testing of asphalt samples was carried out after 20 to 42 hours after their preparation.

\section{Conclusion}

It is known, that in connection with intensive development of various industrial cities, formed a huge amount of solid waste industry that are taking up a huge suitable land, pollute the environment. Academic and technical progress is associated with the maximum savings of material and energy resources, the creation of non-waste technology, the intensification of technological processes and improved quality products.

One of the effective methods of solid waste disposal industry is their use in the design of various types of asphalt.

It should be noted that to date, no research has been conducted on possible use of mineral wastes in the production of asphalt concrete. With that in mind, we have carried out the research work in this direction. It is shown that the use in the production of decorative sand asphalt industrial waste in the form of overburden from the mining of alunite is possible to simultaneously solve two problems - to obtain high economic benefits and improve the ecological condition of the region.

The physical and mechanical properties of highly porous sand-asphalt-concrete are given in the table.

Table 1. Physio-mechanical properties of decorative sand asphalt.

\begin{tabular}{|l|c|c|}
\hline \multicolumn{1}{|c|}{ The name of indicators } & GOST 9128-84 & $\begin{array}{c}\text { The results of calculations } \\
\text { and tests }\end{array}$ \\
\hline The volumetric weight of asphalt, $\mathrm{g} / \mathrm{cm}^{3}$ & - & 2,24 \\
\hline Specific weight of asphalt, $\mathrm{g} / \mathrm{cm}^{3}$ & - & 2,46 \\
\hline The porosity of the mineral part of asphalt concrete, percent & $>28$ & 30 \\
\hline The residual porosity of asphalt concrete, percent & Nomore 6-10 & 9 \\
\hline Water saturation of asphalt concrete, percent & Nomore 18 & 0,18 \\
\hline Swelling of asphalt concrete, percent & Nomore 1-2 & 0,2 \\
\hline \multicolumn{1}{|c|}{ The limit of compressive strength at $20^{\circ} \mathrm{C}, \mathrm{kgp} / \mathrm{sm}$} & $12-14$ & 14,2 \\
\hline Stability at Marshall, $\mathrm{kgp}$ & 150 & 212 \\
\hline Conditional plasticity according to Marshall, $\mathrm{mm}$ & $2-4,7$ & 4,4 \\
\hline The index of conditional rigidity at the Marshal, $\mathrm{kg} / \mathrm{mm}$ & $16-29$ & 22.7 \\
\hline
\end{tabular}

Thus, summarizing the data of the conducted research the overburden rock sealing - wax-red alunite ore can be recommended as filler in the manufacture of decorative sand asphalt.

\section{Acknowledgements}

Work is executed at financial support the Science Development Foundation under the President of the Republic of Azerbaijan-Grant № EIF -2011-1(3)-82/06/1
This asphalt can be used while styling children's playgrounds, parking lots and sidewalks.

\section{References:}

1. Tagiyev, N. I., Rustamov, G. A., \& Ismailov, C. G. (1990). Study of the possibility of obtaining cement-free binders. Resp. conf. Composite materials and environmental issues. (p.28). Ganja.

2. Aliev, F. Y., Sharifova, M. T., Mammadov, E. A., \& Ismailov, C. G. (2012). New highly filled 


\begin{tabular}{|c|c|c|c|c|c|c|}
\hline \multirow{4}{*}{ Impact Factor: } & ISRA (India) & $=3.117$ & SIS (USA) & $=0.912$ & ICV (Poland) & $=6.630$ \\
\hline & ISI (Dubai, UAE & $=0.829$ & РИНЦ (Russia) & $=0.156$ & PIF (India) & $=1.940$ \\
\hline & GIF (Australia) & $=0.564$ & ESJI (KZ) & $=5.015$ & IBI (India) & $=4.260$ \\
\hline & JIF & $=1.500$ & SJIF (Morocco) & $=5.667$ & & \\
\hline
\end{tabular}

composites based on low density polyethylene and industrial waste of the Dashkesan iron deposit. New polymer composite materials. Proceedings of the VIII int. scientific-practical. conf. (p.8). Nalchik.

3. Sharifova, M. T., Ismailov, C. G., Hajiyeva, E. M., Hajiyeva, R. F., \& Aslanova, Z. A. (2015). Synthesis and study of properties of composites recycling of used polyethylene. Collection News of Ganja branch of ANAS, № 4 (62), 56.

4. (2005). Manual construction of road and airfield clothes with asphalt-concrete coating in Azerbaijan. (p.183). Baku.

5. Gorchakov, G. I., \& Bazhenov, Y. M. (1986). Construction materials. (p.687). Moscow, Higher School.

6. (n.d.). Mix asphalt road, airfield and asphalt concrete. Technical conditions. GOST 9128-84.

7. Sərifova, M. T., İsmayılov, C. H., Haciyeva, E. M., Haciyeva, R. F., \& Aslanova, Z. A. (2015). Iş̧ənilmiş polietilendən təkrar emalı üsulu ilə kompozisiyaların alınması və xassələrinin tədqiqi. AMEA Gəncə Bölmasi, "Xəbərlar" macmuәsi № 62, 56-59.

8. Şərifova, M. T., Haciyeva, E. M., Haciyeva, R. F., Babayeva, P. F., \& Aslanova, Z. A (2016). Metallurgiya sənayesi tullantılarının pasportlaşdırılması. AMEA Gancə Bölmasi "Xabarlar macmuasi", № 66, 46-49.

9. Cəfərov, V. C., Aliyev, F. Y., \& Sərifova, M. T. (2015). Polimer kompozisiyast. Patent İ 2015000.

10. Cəfərov, V. C., Aliyev, F. Y., \& Sərifova, M. T. (2016, May 11-13). Qeyri-üzvi birlaşmalarin polietilen matrisli kompozisiyalara tasiri. GDU. Beynolxalq elmi konfrans materialları. (p.3738). Gəncə.

11. Aliyev, F. Y., Sharifova, M. T., Ismayılov, C. G., Budaglı, V. A., \& Mammadova, A. T. (2016). Combined method for processing of hydrochemical Alunite of Zaylik ore deposits. ISJ Theoretical \& Applied Science, 08 (40), 1922. 